\title{
Impacts of drought on the quality of surface water of the basin
}

\author{
B. B. Huang ${ }^{1,2}$, D. H. Yan $^{1}$, H. Wang ${ }^{1}$, B. F. Cheng ${ }^{1}$, and X. H. Cui ${ }^{1}$
}

${ }^{1}$ Water Resources Department, China Institute of Water Resources and Hydropower Research, Beijing, 100044, China

${ }^{2}$ Provincial Key Laboratory of Hydrology-Water Resources and Water Environment, Nanchang Institute of Technology, Nanchang, 330099, China

Received: 12 November 2013 - Accepted: 14 November 2013

- Published: 26 November 2013

Correspondence to: B. B. Huang (nithuang@nit.edu.cn)

Published by Copernicus Publications on behalf of the European Geosciences Union.

Impacts of drought

on the quality of

surface water of the basin

B. B. Huang et al.

\section{Title Page}

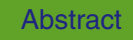

Introduction

Conclusions

References

Tables

Figures

14

$\rightarrow$

Back

Close 


\section{Abstract}

Under the background of climate change and human's activities, there has been presenting an increase both in the frequency of droughts and the range of their impacts. Droughts may give rise to a series of resources, environmental and ecological effects, 5 i.e. water shortage, water quality deterioration as well as the decrease in the diversity of aquatic organisms. This paper, above all, identifies the impact mechanism of drought on the surface water quality of the basin, and then systematically studies the laws of generation, transfer, transformation and degradation of pollutants during the drought, finding out that the alternating droughts and floods stage is the critical period during which the surface water quality is affected. Secondly, through employing indoor orthogonality experiments, serving drought degree, rainfall intensity and rainfall duration as the main elements and designing various scenario models, the study inspects the effects of various factors on the nitrogen loss in soil as well as the loss of nonpoint sources pollution and the leaching rate of nitrogen under the different alternating scenarios of drought and flood. It comes to the conclusion that the various factors and the loss of non-point source pollution are positively correlated, and under the alternating scenarios of drought and flood, there is an exacerbation in the loss of ammonium nitrogen and nitrate nitrogen in soil, which generates the transfer and transformation mechanisms of non-point source pollution from a micro level. Finally, by employing the data of Nenjiang river basin, the paper assesses the impacts of drought on the surface water quality from a macro level.

\section{Introduction}

Drought is a natural phenomenon when there is an abnormal climate, and it's also a normal law under the climate regulation for a long time (Wilhite, 2000). Drought gives rise to a series of resources, environmental and ecological effects, i.e. water shortage, water deterioration as well as the decrease in the diversity of aquatic organisms. With
HESSD

$10,14463-14493,2013$

Impacts of drought

on the quality of

surface water of the

basin

B. B. Huang et al.

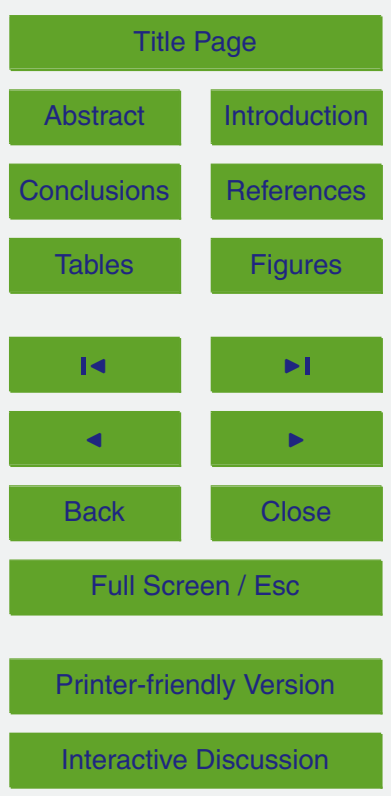


the rapid development of social economy, people's demands for water resources have been on a gradual increase. Nowadays, under the competitive situation of water-use, the use of water in the social economic system will occupy the part of which being used for the biological environment, especially noticeable when there is a drought. Under the 5 same natural condition, a drought will make the situation even worse.

Historical monitoring data and the assessment reports of IPCC make it clear that the occurrence of drought in some areas becomes more frequent and the duration becomes longer at the same time. In China, runoff volume in some rivers and lakes has decreased noticeably (Liu, 1997; Zhang, 2008). For years, scholars at home and 10 abroad have made a great number of researches focusing on the impacts of drought on water environment. These researches consist of three different stages: the embryonic stage, the growth stage and the development stage. Rudimentary stage (before 21st century): most scholars at home and abroad did researches on the water environment of the drought periods as well as the drought areas, mainly focusing on the physicochemical property of water bodies during the drought and the water environment in drought areas; meanwhile, they briefly explored the causes of water deterioration in the drought periods (Whitehead, 2009; Margarida, 1995; Peter, 2007). Their studies were mainly described qualitatively (Chang, 1999; Tarrad et al., 1991; Gomez, 1996; Wang, 1998). Growth stage (2000-2006): researchers, from the perspective of climatic change, studied the changes in physical, chemical and biological indexes of water quality which were caused by the variations of the climatically hydrological factors (temperature, rainfall, river flow, etc.) in order to identify the impact mechanism of drought on the water environment (Caruso, 2002; Mimikou, 2000; Zhan, 2005; Senhorst, 2005; Zwolsman, 2007). Development stage (from 2007 up to now): researchers began to analyze the impact of drought on water environment at the mechanism level. They have been carrying out different researches on the water quality of surface water bodies in actual drought situations, and combining regional characteristics into their researches, they have tried to analyze the transformation features of the pollutants among the water bodies under the scenario of droughts as well as the problems of water environment
HESSD

10, 14463-14493, 2013

Impacts of drought

on the quality of

surface water of the

basin

B. B. Huang et al.

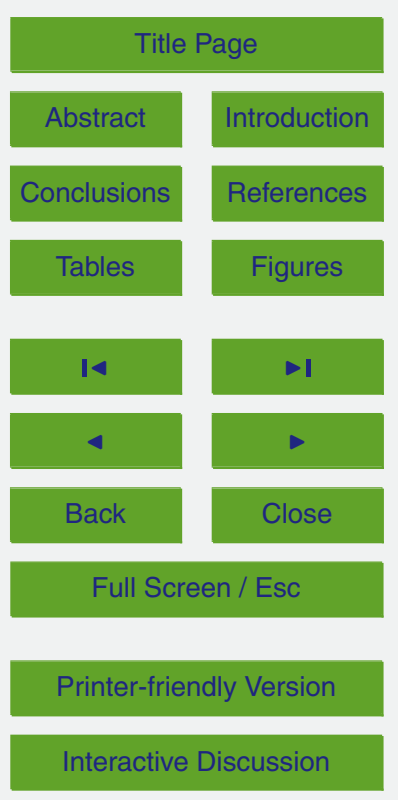


caused by them (George, 2007; Lunchakorn, 2008; Van der Wiele et al., 2010; Delpla, 2009; Harmke, 2006; Zowlsman, 2008). To sum up, researches at present are focused on the impacts of drought on water quality, the relationship between droughts and pollutants in water bodies as well as the physical and chemical reactions in water bod-

5 ies during the drought, etc. However, researches on the following areas, such as the changing mechanism of surface water quality during the drought, the identification of the main factors which affect the loss of non-point (source) pollution, and the alleviation of impact of drought on water environment, are badly needed.

This paper, at the very beginning, identifies the impact mechanism of drought on the 10 surface water quality of the basin, analyzes the impact of rainfall on the surface water quality before and after a drought, studies the laws of how pollutants are formed, how they enter the rivers and how they are transferred and transformed in the river channels. Then drought degree, rainfall intensity and rainfall duration are chosen as the main elements; at the same time, orthogonality experiments are conducted to simulate the dynamical changing process of nitrogen in the agricultural topsoil under the different scenarios of dry-and-wet process. The paper also reveals the transformation mechanism of non-point source pollution during the alternating periods of drought and flood, and analyzes how much impact the various factors and scenarios has on the river water quality. Finally, by using the observed data of Nenjiang river basin, the paper assesses the impact of drought on the surface water quality of the basin from the level of river basin.

\section{Identifications of the basic impact mechanism of drought on surface water quality of the basin}

Water is the carrier of the basin substances and energy flow. The process of water extreme process of water cycle. Hydrological extreme events, droughts for instance, affect the runoff generation and confluence mechanism of the basin, and change the

Impacts of drought

on the quality of

surface water of the basin

B. B. Huang et al.

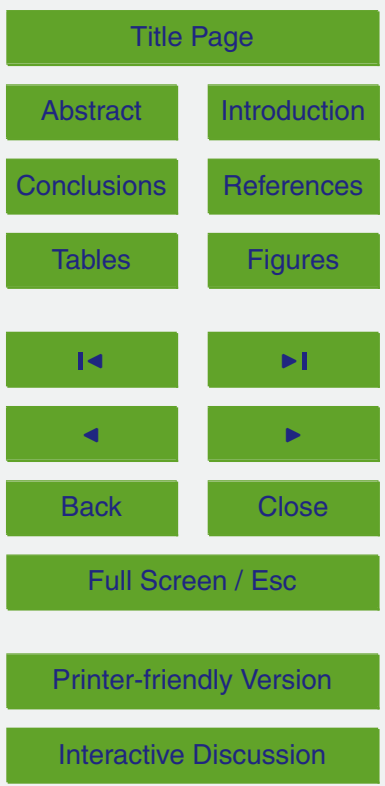


pollutants transformation and the dilution capacity of water bodies. The human activities (such as taking, supply, using, consumption, drainage, etc.) interfere the cycling process of natural water. For example, using water will change the water volume, and drainage will change the water quality. Under the background of the climate change 5 and human's activities, changes could take place in the laws of generation, transfer and diffusion of river basin pollutants. In the first place, the deficiency of rainfall during the drought damages the balance of the surface water, giving rise to the reduction of the water supply, the aggravation of evaporation, the drop of water table and the shrink of river and lake basin. Secondly, during the drought, the increase of the concentration 10 of nutrition elements (i.e. nitrogen, phosphorus and so on), the weakening of the hydrodynamic conditions and the extension of the dwell time will provide sufficient nutrition for algae's rapid multiplication, leading to the aggravation of eutrophication, the disorder of the aquatic ecosystem, the reduction of the living species and the damage of diversity. Finally, the mechanism of runoff generation and confluence is altered during the drought, leading to the variations of the total number, components and diffusion of pollutants in the river basin. The rainfall after the drought, in particular, will bring the accumulated non-point source pollution into the water body, resulting in the deterioration of water quality. Therefore, if we want to know exactly how drought impacts the surface water quality by studying impacts of drought on the generation, transfer and degradation rules with regards to water content and pollutants, climate change and human activities must be taken into consideration.

\subsection{Impacts of drought on pollution sources and pollutant generation quantity}

The surface water quality of the basin is affected by both the point source pollution (industrial waste water and domestic sewage) and non-point source pollution. With 25 the point source pollution being reduced gradually, the non-point source pollution has become the main factor of the surface water degradation in China now. Urban runoff and agricultural runoff are the two types of non-point source pollution, while surface runoff and interflow are the carriers which make the non-point source pollution enter

\section{HESSD}

10, 14463-14493, 2013

Impacts of drought

on the quality of

surface water of the

basin

B. B. Huang et al.
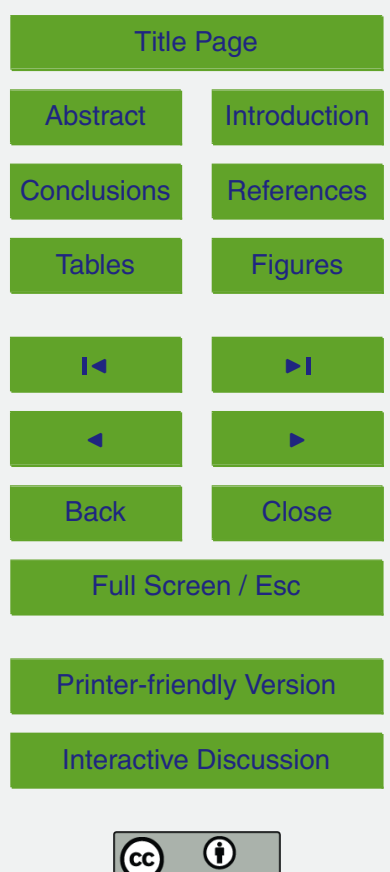
into the water body. During the drought, due to the decrease of rainfall and runoffs, nonpoint source contaminants which flow into the surface water become less. As a result, pollutants of surface water body during the drought mainly belong to the point source pollution.

5 During the dry period, for a lack of formation process of runoff, domestic refuses, wastes and non-point source contaminants alike are piled up in the earth's surface and soil. When the rain falls, they will fall into the receiving water body along with runoffs. The dry-wet alternation from drought to rainfall will promote the decomposition of the organic matters in soil and increase the load of nutrients in water, which lead 10 to a rapid deterioration of surface water quality in a short time (the major exceeding items are nutrient salt and suspended solids). Compared with the draught season, the precipitation events after the drought exert a greater influence on the water quality. Therefore, the alternating drought and flood stage is the most important one which affects the surface water quality of a basin.

\subsection{Impacts of drought on the transformation process of pollution}

The contaminants finish their process of transfer and transformation in atmospheresoil-water through water cycle. The impacts of drought on the migration and transformation of contaminants in various mediums are as follows:

\subsubsection{Atmosphere}

During the drought, temperature rises and evaporation amount increases. As a result, there is an increase of pollutants that enter the atmosphere through evaporation, while pollutants that go back to the water and soil through precipitation drop. When it rains for the first time after the drought, the pollutants in the air will fall onto the earth's surface, resulting in an increase of them in the run-offs.

\section{HESSD}

$10,14463-14493,2013$

Impacts of drought

on the quality of

surface water of the

basin

B. B. Huang et al.

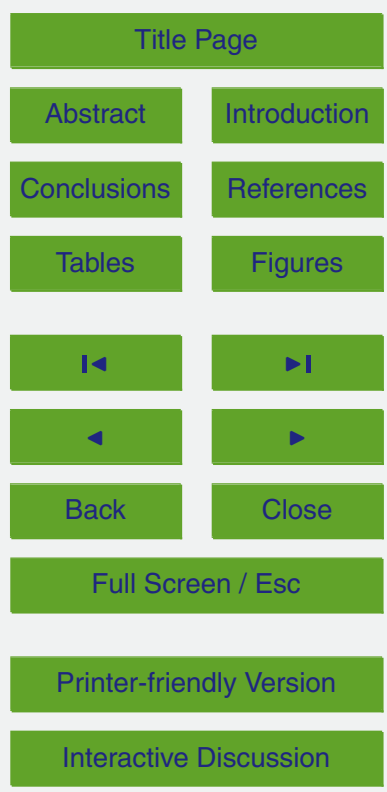




\subsubsection{Soil}

The main transformation process of contaminants in the soil consists of absorption, desorption, diffusion, evaporation and degradation. Drought exerts an impact on the soil moisture, solute transfer and temperature, which alters the transfer law of the pol-

5 lutants in the soil. The temperature of soil affects the edaphon and enzymatic activity, the speed of soil reaction and the rate of soil respiration. A rise in the temperature will promote the decomposition of organic contaminants in the soil. If there is less soil moisture, there will be more organic contaminants which are absorbed into the soil particles and reside in the soil in the solid form. Whenever it rains after a drought, the 10 organic contaminants which have been piled up for a long time during the drought will migrate with the run-offs.

\subsubsection{Water}

On account of a shortage of precipitation and run-offs during the drought period, pollutants are piled up in the soil and the earth's surface. When it rains, the pollutants flow 15 into the river courses in the wake of surface and subsurface runoffs. Along with the move of the water, the pollutants in the river courses will lessen the density of the pollutants through physical, chemical and biological actions as well as their own dispersion, attenuation and transformation. When there is a drought, there will be a decrease in the discharge of water in the river channels, a gradual worsening of the hydrodynamic condition, a reduction in the velocity, a deposition of sediments and contaminants as well as an increase of resident time of the pollutants in the water body. All these will lead to the reduction of water quality.

\subsection{Impacts of drought on the channel pollutants and surface water quality}

During the drought, a decrease in the channel flow and velocity as well as the capacity

HESSD

10, 14463-14493, 2013

Impacts of drought

on the quality of

surface water of the

basin

B. B. Huang et al.

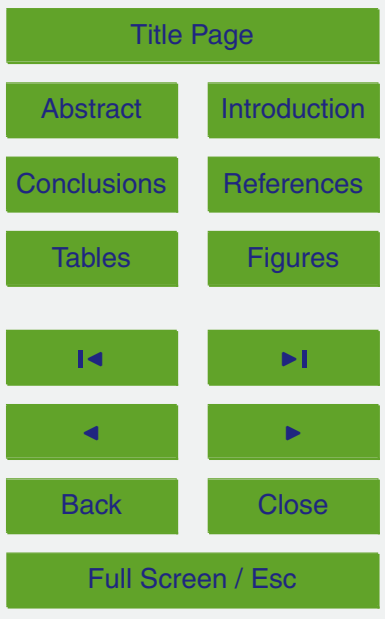

Printer-friendly Version

Interactive Discussion 
nutrition elements (i.e. nitrogen, phosphorus and so on), the weakening of the hydrodynamic conditions and the extension of the dwell time will provide sufficient nutrition for algae's rapid multiplication, leading to an aggravation of eutrophication, a disorder of the aquatic ecosystem, a reduction of the living species and a damage of the diver-

5 sity. A large quantity of sediments and pollutants are accumulated in the bottom of the river, which breaks the balance of the deposition and suspension of the downriver sediments and increases the oxygen consumption of suspended particles and pollutants, leading to a decrease in the pollutant carrying capacity and an increase in the density of pollutants.

10 The decomposition of the organics by microorganisms consumes the dissolved oxygen in the water. As a result, with the level of the dissolved oxygen decreasing, toxic materials enter the aquatic organisms, resulting in their deaths. Therefore, more dissolved oxygen is needed to decompose their bodies. The entry of nutrients into the water body causes the algae and other plankton multiply rapidly. They gradually take up the surface of the water and consume a great amount of dissolved oxygen. When the dissolved oxygen in water is used up, the organics begin their anaerobic decomposition, which produce some unpleasant gases such as hydrogen, mercaptan, etc., and make the water quality deteriorate.

A rise in temperature during the drought, at first, affects the physical and chemical property of the water bodies, for example, the solubility of a gas, the speed of chemical and biochemical reaction, and the impacts of water temperature on the activities of microorganism. Secondly, it affects the inner process of the water body; for instance, the process of diffusion, mineralization and vertical mixing changes the temperature between the metalimnion and the stratosphere, which can easily generate the stratifi25 cation of the water body. It also speeds up the oxic reaction, leading to the decrease of the dissolved oxygen. The levels of ammonia nitrogen, nitrite and phosphate rise, while there is a drop in nitrates. Besides, it reactivates the toxic organics, which will cause an extra pollution of the water body. Finally, it makes the algae multiply rapidly, which in turn will destroy the ecological balance of water and cause the water eutrophication.

\section{HESSD}

10, 14463-14493, 2013

Impacts of drought

on the quality of

surface water of the

basin

B. B. Huang et al.

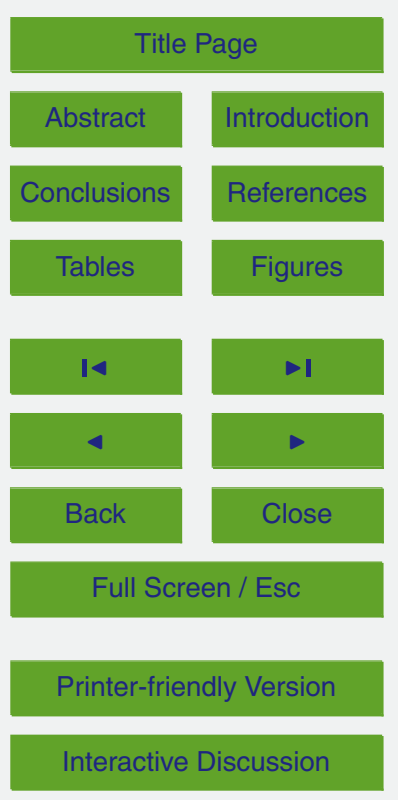




\section{Experimental materials and designs}

\subsection{Design of drought scenario}

By employing the indoor orthogonality experiments, serving the drought degree, rainfall intensity and rainfall duration as the main factors, the study inspects the impacts of

5 various factors on the nitrogen loss in soil as well as the loss of non-point sources pollution and the leaching rate of nitrogen under the different alternating scenarios of drought and flood.

In order to keep the actual drought process of the soil in the study area, the soil sample collected from the field was put into the incubator (LHS-250SC). The temperature of the incubator was kept at $26.9^{\circ}$ (mean monthly maximum temperature in Daxing Region, Beijing) and the humidity was kept at $69 \%$ (mean yearly relative humidity in Daxing Region, Beijing). The relative soil moisture $(W)$ was served as the criterion to appraise the soil drought degrees (see Table 1). The soil moisture content was monitored continuously, and the soil in the light of the four drought scenarios (i.e. mild, moderate, severe and extraordinary) was cultivated respectively.

The calculating formula of the relative soil moisture $(W)$ - see Eq. (1).

$W=\theta / F_{\mathrm{c}} \times 100 \%$.

$\theta$ - average weight water content of soil (\%); $F_{\mathrm{c}}$ - field moisture capacity of soil (\%).

\subsection{Design of rainfall scenario}

20 The soil of the previous four drought scenarios was watered and dealt with simulated rainfall. The alternating scenario of drought and flood was simulated in order to find out how rainfall duration affects the nutrients contents in soil of the different drought degrees (see Table 2). Through designing different kinds of rainfall intensity, we simulated how the different kinds of rainfall intensity led to the nitrogen loss of the drought soil and the soil belonging to different drought degrees by the same rainfall intensity (see

Impacts of drought

on the quality of

surface water of the basin

B. B. Huang et al.

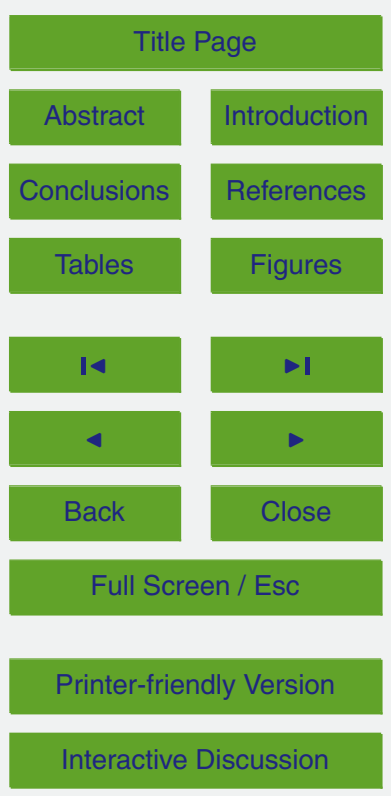


Table 3). The leakage water from the lateral side of the soil sample was collected after the rainfall, and then it was tested, along with the content of the ammonia nitrogen and nitrate nitrogen.

\subsection{Experimental materials and equipments}

5 The experiment was carried out at Daxing Experimental Base (belongs to China Institute of Water Resources and Hydropower Research) in Beijing. The surface soil used for testing was taken from the maize planting area at Daxing Experimental Base. The soil type was fluvo-aquic soil. See Table 4 for its basic physical and chemical properties. See Fig. 1 for rainfall simulator. The water speed and volume are controlled by a control valve, while the outfall intensity of the sprinkler used for rainfall simulation was controlled by a pressure valve. The rainfall simulator can simulate a heavier rainfall at a relatively authentic level.

\subsection{Calculation of the leaching rate of nitrogen and pollution-yield rate}

At the beginning of the rainfalls, the surface soil moisture reaches its saturation rapidly as a result of plants interception and soil infiltration. The transfer of nitrogen is an associated process of water cycle. The experiment simulates the generation of runoffs under the different alternating scenarios of drought and flood, and calculates the leaching rate (LR) of nitrogen and pollution-yield rate (PR). See Eqs. (2) and (3) for the calculating methods.

$\operatorname{LR}=\frac{N_{\mathrm{W}}}{N_{\mathrm{S}}}$

$\mathrm{PR}=\frac{N_{\mathrm{W}}}{N_{\mathrm{L}}}$

$N_{\mathrm{W}}$ - content of $\mathrm{NO}_{3}-\mathrm{N}$ and $\mathrm{NH}_{4}-\mathrm{N}$ in leakage liquid, $\mathrm{N}_{\mathrm{S}}-$ content of $\mathrm{NO}_{3}-\mathrm{N}^{2}$ and $\mathrm{NH}_{4}-\mathrm{N}$ in soil before the rainfall, $\mathrm{N}_{\mathrm{L}}$ - loss of $\mathrm{NO}_{3}-\mathrm{N}$ and $\mathrm{NH}_{4}-\mathrm{N}$ in soil after the rainfall.
HESSD

$10,14463-14493,2013$

Impacts of drought

on the quality of

surface water of the

basin

B. B. Huang et al.

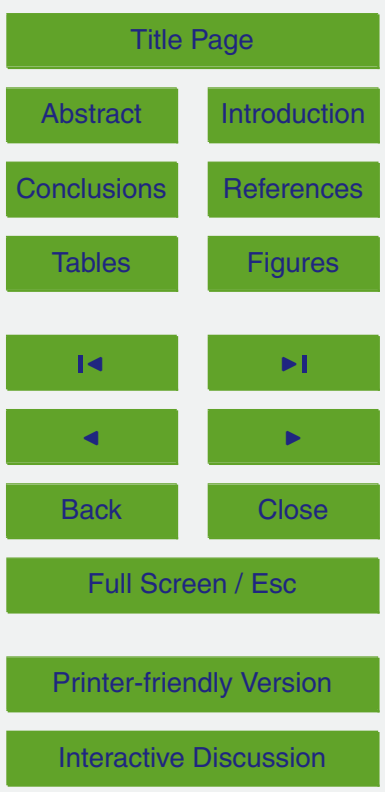

Interactive Discussion 


\subsection{Results and discussions}

The impact of rainfall duration on the nitrogen loss in the soil is shown in Fig. 2. As is shown in the figure, when the soil moisture contents are identical, in other words, when the drought degrees are identical, the longer the rainfall duration is, the more ammonia 5 nitrogen and nitrate nitrogen loss in the soil will be. When the rainfall durations are the same, the higher drought degree will lead to greater loss of ammonia nitrogen and nitrate nitrogen. Compared with ammonia nitrogen, nitrate nitrogen is more significantly affected by the rainfall duration.

The experiment shows that droughts will aggravate the loss of ammonia nitrogen in 10 the surface soil. With the aggravation of the drought degree, there will be a rise in the soil temperature, an increased mineralization of nitrogen in the soil and a raise in the ammonia nitrogen content. Higher soil moisture content and better soil ventilation will enhance the microbiological activities, which reinforces the transformation from urea nitrogen to ammonium nitrogen. The formation of runoffs and partial infiltration of soil moisture are the two major ways that cause the loss of ammonia nitrogen in the soil. The during-after rainfalls result in an increase of ammonia nitrogen loss in surface water.

Rainfall duration will worsen the loss of nitrate nitrogen existing in surface soil. Besides, as the drought degree gears up, this impact will be enlarged. Nitrate nitrogen is the main residue of fertilizer $\mathrm{N}$ which permeates the soil but is not absorbed by plants, and it moves along with the water flow. To the soil of lower drought degree, its infiltration capacity is strong; therefore, a large amount of nitrate nitrogen infiltrates into the deep subsoil in the wake of moisture. The soil of severe drought degree will become hardened and impervious. The heavy runoff during the rainfall results in a mass loss of nitrate nitrogen in the field surface soil.
HESSD

10, 14463-14493, 2013

Impacts of drought

on the quality of

surface water of the

basin

B. B. Huang et al.

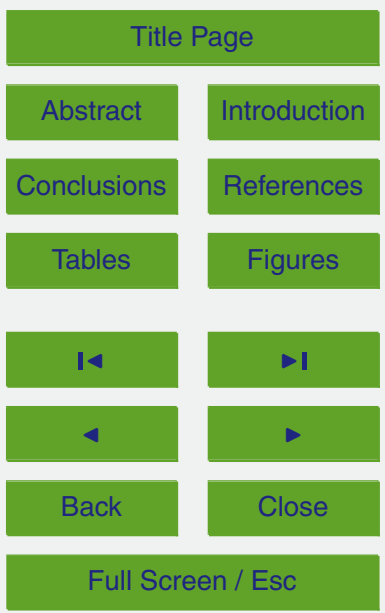

Printer-friendly Version

Interactive Discussion 


\subsubsection{Impacts of rainfall intensity on the nitrogen loss in the soil of various drought degrees}

Impacts of rainfall intensity on the leaching amount of agricultural non-point source pollution are demonstrated in Fig. 3. As is shown in Fig. 3, when the soil moisture contents are identical, if the rainfall intensity is greater, more ammonia nitrogen and nitrate nitrogen in the soil will be lost. When the rainfall intensity is the same, the higher drought degree will lead to greater loss of ammonia nitrogen and nitrate nitrogen. Compared with ammonia nitrogen, nitrate nitrogen is more significantly affected by the rainfall intensity.

10 The impact mechanism of rainfall intensity on the nitrogen loss in the soil is identical to the one of rainfall duration. In addition, rainfalls of high intensity aggravate the infiltration of soil moisture and the loss of ammonia nitrogen. The impacts of raindrops desorb the nutrients that absorb on the soil particle, resulting in a rise of the nutrient concentrations that enter the runoffs. At the same time, raindrops disperse the soil

\subsubsection{Leaching rate of nitrogen and pollution-yield rate under the alternating scenarios of drought and flood}

Ammonium nitrogen can be directly absorbed by plants and can be solved in water easily. It will be transformed into nitrate nitrogen in the soil of good ventilation, easily 20 giving rise to nitrogen leaching and loss. In the alternating droughts and floods stage, nitrogen form in soil changes. The leaching and loss of nitrogen in soil not only generates the nitrates pollution in underground water, but also results in the loss of nitrogen in the wake of surface runoffs, which causes the deterioration of surface water quality. The leaching rate of nitrogen under different alternating scenarios of drought and flood can be estimated by using indoor simulation date and Eq. (2), see Tables 5 and 6.

Due to the excessive use of chemical pesticides and fertilizers, a great amount of nitrogenous fertilizer remains in the soil. Evaporation leads to a rise in nitrogen in the$$
14474
$$

HESSD

$10,14463-14493,2013$

Impacts of drought

on the quality of

surface water of the

basin

B. B. Huang et al.

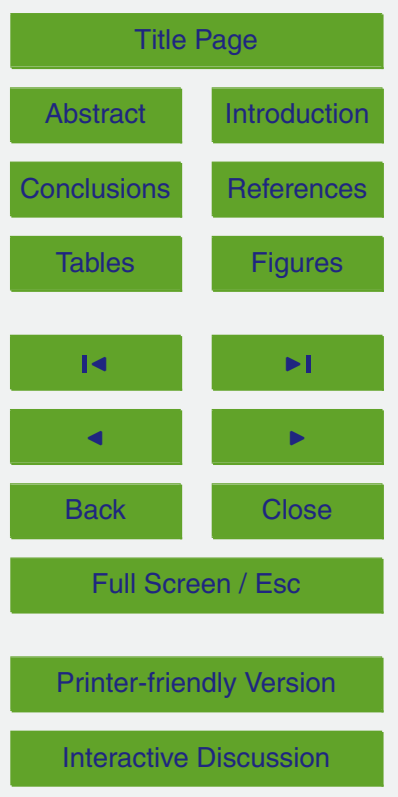


wake of moisture, and it piles up gradually in the surface soil. With a high temperature condition, enzymatic activity enhances, which promotes the nitration. An increase in nitrates intensifies nitrogen leaching. The pollution-yield rate under different alternating scenarios of drought and flood can be estimated by using Eq. (2), see Tables 7 and 8.

5 As is shown in Tables 5-8, the leaching rate and pollution-yield rate of ammonium nitrogen and nitrate nitrogen are negatively correlated with soil moisture content, while positively correlated with rainfall intensity. Under the scenario of extraordinary droughtrainfall $\left(3.5 \mathrm{~mm} \mathrm{~min}^{-1}\right)$, the leaching rate and pollution-yield rate of ammonium nitrogen and nitrate nitrogen reach the highest point, which denotes that drought and extreme 10 rainfall not only aggravate the nitrogen loss in soil, but also boost the nitrogen content in surface runoffs, resulting in increasing impacts of non-point source pollution on surface water quality.

Compared with ammonium nitrogen, nitrate nitrogen has a higher rate of leaching and pollution yield and is more significantly affected by droughts and rainfalls. With an increase in rainfall intensity, there will be an increase both in the leaching rate and pollution-yield rate of ammonium nitrogen and nitrate nitrogen in the soil of various drought degrees. It proves that, to some extent, rainfall intensity affects the ways of nitrogen leaching, and nitrate nitrogen loses mainly in the way of surface runoffs under the scenario of extraordinary drought-rainfall $\left(3.5 \mathrm{~mm} \mathrm{~min}^{-1}\right)$.

\section{Assessment of the impact of basin scale}

For the purpose of verifying the impacts of droughts of different degrees and the afterdrought rainfalls on the surface water quality of the basin, this section of the paper analyzes the water quality data of different periods from the embankments of Kumotun, Fulaerji and Jiangqiao in Nenjiang Basin. The monitoring data of water quality in this paper are taken from Monitoring Results of Environmental Quality of Surface Water in Heilongjiang Province, Monitoring Results of Environmental Quality of Surface Water in Jilin Province and Monitoring Results of Environmental Quality of Surface Water in

\section{HESSD}

10, 14463-14493, 2013

Impacts of drought

on the quality of

surface water of the

basin

B. B. Huang et al.

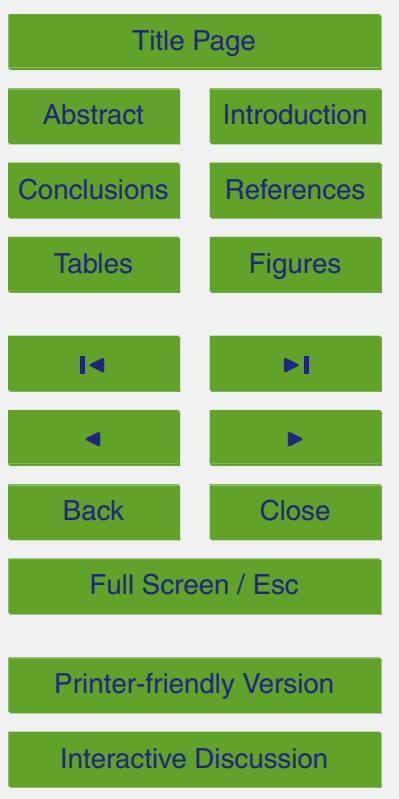


Neimenggu Province from 2000 to 2006 . The continuous days of effective rainfall free (Dry spell) is used as one of the indictors of drought during the crop growth period (Chen, 2010), see Table 8. The changes of different water quality indexes of various drought degrees during the drought period and of the first rainfall after the drought in

5 Nenjiang Basin during the summers (June to August) of 2000-2006 are analyzed. The features of water quality change under the different alternating scenarios of drought and flood are identified, see Fig. 4.

As is shown in Fig. 4, there presents an upward trend in the density of COD, ammonium nitrogen and nitrate nitrogen in Kumotun, Fulaerji and Jiangqiao when the drought 10 degrees increase, while there is no significant change in $\mathrm{BOD}_{5}$. The overall water quality becomes worse. The significance of growth trend is varied too. The growth trend of COD density is significant, and the growth rate is most conspicuous when the drought degree increases from the severe level to extraordinary one. Theoretically, higher temperature will enhance the self-purification of $\mathrm{BOD}_{5}$. Meanwhile, due to the reduction 15 of runoffs during drought, they two offset each other. The density variation of $\mathrm{BOD}_{5}$ is not significant. During the drought, point source pollution dominates, and the density of COD is significantly higher than of ammonium nitrogen. Therefore, as the drought degrees deepen, density of COD, ammonium nitrogen and nitrate nitrogen increases at the same time; it constitutes a more serious impact on COD. The impact of $\mathrm{BOD}_{5}$ on drought is not significant. Water quality deteriorates.

As can be seen from Fig. 4, when it rains after a drought lasts for a period of time, there is a more significant increase in the density of COD, ammonium nitrogen and nitrate nitrogen in Kumotun, Fulaerji and Jiangqiao than it is during the dry spell. There is the most significant increase in density of COD, ammonium nitrogen and nitrate nitrogen resulted from the rainfall after a drought, while the change of BOD5 of the three embankments is not significant. After the rainfall, water resources increase to some extent. The majority of pollutants piled up in the earth's surface, mainly nonpoint sources pollution - the main reason of ammonium nitrogen change, enter the surface water in the wake of runoffs because of rain wash and soil erosion. Due to the
HESSD

10, 14463-14493, 2013

Impacts of drought

on the quality of

surface water of the

basin

B. B. Huang et al.

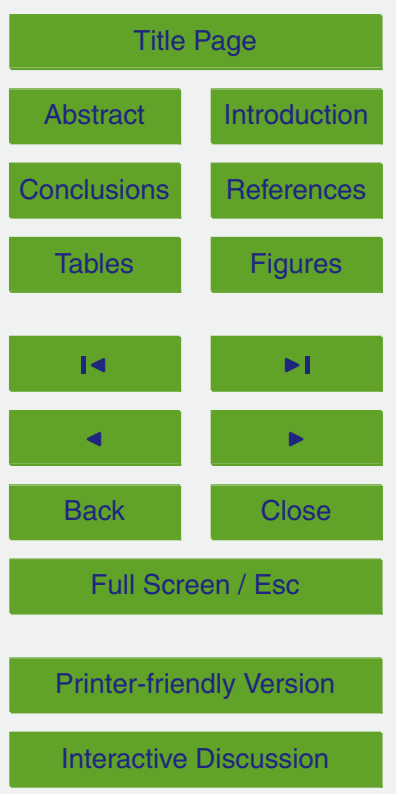


supplements of rainfalls, underground water level rises. The underground water flows into the surface water along with river runoffs, resulting in an increase of pollutants in the water. A rainfall after a drought leads to an increase in water resources as well as an increase in the number of pollutants in the water. The rapid growth of pollutants 5 results in a water quality deterioration in the surface water in a short time, and the water ecological environment worsens.

In the light of the case analysis of Nenjiang river basin, it can be concluded that: the higher the drought degree is, the worse the surface quality of a basin will be; the main source which affects the water quality during the drought is point source pollution; the

10 first rainfall after a drought is the key factor which gives rise to the change of water quality in the surface water of a basin and exerts a greater impact on water quality; meanwhile, non-point pollution is the main source. The case of Nenjiang river basin proves the correctness of the theoretical analysis.

\section{Conclusions and prospects}

15 Taking climate change and human's activities as the background, this paper identifies the mechanisms of pollutants' generation, transfer and transformation in the circulation process of dualistic water cycle, as well as the main factors that affect the water quality of the river basin during the drought. The main findings are as follows:

Firstly, climate change and human's activities are at present the main causes that 20 give rise to the deterioration of water environment in the basin area during the dry period; however, the key factors that determine the water quality are a decrease in the river discharge, a rise in the temperature and runoffs' scouring towards non-point source pollutants during the rapid alternating period of drought and flood.

Secondly, with the aggravation of drought, the density of ammonia nitrogen, COD 25 and nitrates in water will increase. A rise in temperature will enhance the selfpurification capacity of BOD5 in water, but there is no significant change in BOD5 density due to the reduction of discharge during drought.

\section{HESSD}

10, 14463-14493, 2013

Impacts of drought

on the quality of

surface water of the

basin

B. B. Huang et al.

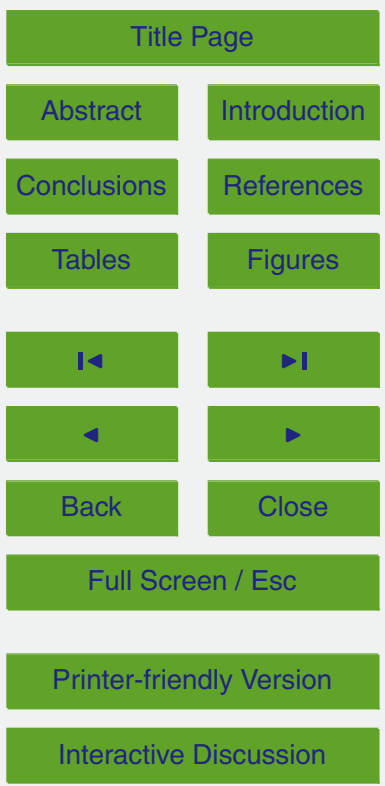


Finally, drought degree, rainfall duration and intensity are the three main factors that play a role in the loss of non-point source pollution. When the rainfall duration is identical to the rainfall intensity, there will be an increase in drought degree as well as an increasing loss of non-point source pollution. When the drought degrees are at the 5 same level, rainfall duration and intensity will enhance the loss of non-point source pollution. Under the alternating scenarios of droughts and floods, there will be a greater loss of ammonia and nitrate nitrogen in soil. Under the combining scenario of extraordinary drought-rainfall $3.5 \mathrm{~mm} \mathrm{~min}^{-1}$, the loss of non-point source pollution is the most serious and the pollution rate reaches at $76.4 \%$.

With a setting of climate change and human's activities, the impact of drought on water environment is a complicated process. Therefore, it is quite urgent to develop some simulation models of water environment system, come up with some scientific assessment methods used to assesses the impact of drought on water environment quantitatively, and do research on the emergency management and comprehensive measures towards the extreme hydrological events on the basis of the analysis and forecast of the impact of droughts on water environment.

Acknowledgements. Project $(51309129,51109224)$ Supported By NSFC; Supported by Foundation of Jiang'xi Science and Technology Department (20123BBG70215), Non-profit Industry Financial Program of MWR (201201016).

\section{References}

Barros, M. C., Mendo, M. J. M., and Negrao, F. C. R.: Surface water quality in Portugal during a drought period, Sci. Total Environ., 171, 69-76, 1995.

Caruso, B. S.: Temporal and spatial patterns of extreme low flows and effects on stream ecosystems in Otago, New Zealand, J. Hydrol., 257, 115-133, 2002.

25 Chang, X. L., Zhao, A., and Li, S. G.: Spatial-temporal scale and herarehy of vutnerahle ecotone, J. Desert Res., 19, 115-119, 1999.

Chen, L., Zhai, P., and Zheng, Z.: Features of temporal and spatial variation in Northern China during extreme dry spell in the next half year, Plateau Meteorol., 29, 403-411, 2010.

\section{8}

\section{HESSD}

10, 14463-14493, 2013

Impacts of drought

on the quality of

surface water of the

basin

B. B. Huang et al.

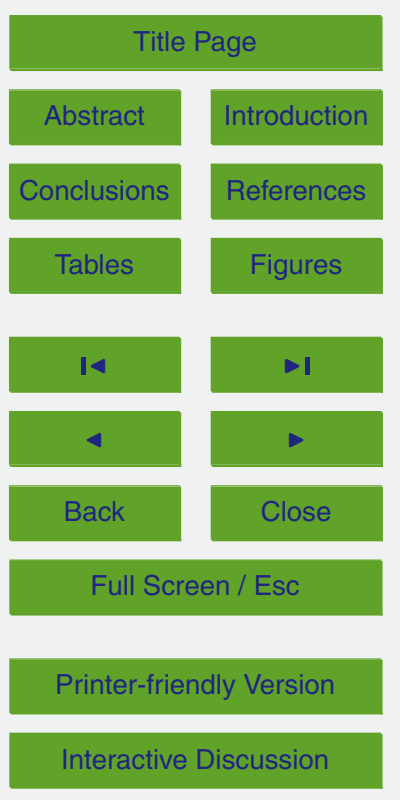


Delpla, I., Jung, A. V., Baures, E., Clement, M., and Thomas, O.: Impacts of climate change on surface water quality in relation to drinking water production, Environ. Int., 35, 1225-1233, 2009.

George, G., Hurley, M., and Hewitt, D.: The impact of climate change on the physical characteristics of the larger lakes in the English Lake District, Freshw. Biol. 52, 1647-1666, 2007.

Gomez, J. M.: Predispersal reproductive ecology of an arid-land crucifer, Moricandia moricandioides-effect of mammal herbivote oil seed production, J. Arid Environ., 33, 425437, 1996.

Liu, C.: Potential impact of climate change on hydrology and water resources in China, Adv. Water Sci., 8, 220-225, 1997.

Mimikou, M. A., Baltas, E., Varanou, E., and Pantazis, K.: Regional impacts of climate change on water resources quantity and quality indicators, J. Hydrol., 234, 95-109, 2000.

Murdoch, P. S., Baron, J. S., and Miller, T. L.: Potential effects of climate change on surfacewater quality in North America, J. Am. Water Resour. Assoc., 36, 347-366, 2007.

15 Prathumratana, L., Sthiannopkao, S., and Kin, K. W.: The relationship climatic and hydrological parameters to surface water quality in the Mekong River, Environ. Int., 34, 860-866, 2008.

Senhorst, H. A. J. and Zowlsman, J. J. G.: Climate change and effects on water quality: a first impression, Water Sci. Technol., 51, 53-59, 2005.

Tarrad, A., Younis, A., Nasr, M., Kasseh, T., Bishay, A., and Dregne, H.: Evaluation of drought and salinity resistance of some Atriplex species in the northwestern Egyptian coast, in: Desert Development Part 1: Desert Agriculture, Ecology and Biology, Harwood Academic publishers, Chur, Switzerland, 1991.

Van Bokhoven, A. J.: The impact of climate change on the water quality of the Rhine river, Kowa Water Res., 56, 423-440, 2006.

Van der Wiele, J., Van Moorselaar, I., and Van der Grinten, E.: Impact of climate change on water quality in the Netherlands, RIVM, 2010.

Van Vliet, M. H. T. and Zowlsman, J. J. G.: Impact of summer droughts on the water quality of the Meuse river, J. Hydrol., 353, 1-17, 2008.

Wang, G. X. and Cheng, G.: Characteristics of spatial he r-erogenetty on environment in inland river basin, Acta Geogr. Sin., 18, 355-361, 1998.

Whitehead, P. G., Wilby, R. L., Battarbee, R. W., Kernan, M., and Wade, A. J.: A review of the potential impact of climate change on surface water quality, Hydrolog. Sci. J., 54, 101-123, 2009.
HESSD

10, 14463-14493, 2013

Impacts of drought

on the quality of

surface water of the

basin

B. B. Huang et al.

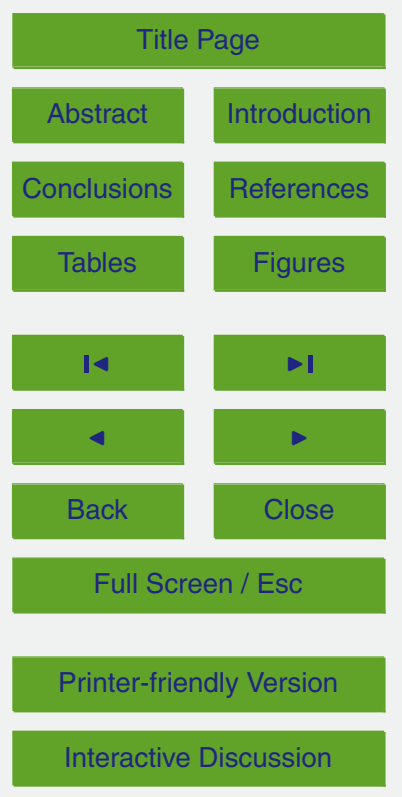


Wilhite, D. A.: Drought as a Natural Hazard: Concepts and Definitions, Routledge, London and New York, 2000.

Zhang, J.: Impacts of climate change on water and science problem, Water Resour. China, 2, 14-18, 2008.

5 Zhu, Z., Arp, P. A., Mazumder, A., Meng, F., Bourque, C. P. A., and Foster, N.: Modeling stream water nutrient concertrations and loadings in response to weather condition and foreast harvesting, Ecol. Model., 185, 231-243, 2005.

Zwolsman, G. and Vanbokhoven, J.: Impact of summer drought on water quality of Rhine River - a preview of climate change, Water Sci. Technol., 56, 45-55, 2007.

Impacts of drought

on the quality of

surface water of the basin

B. B. Huang et al.

Title Page

Abstract

Introduction

Conclusions

References

Tables

Figures

14

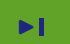

4

Back

Close

Full Screen / Esc

Printer-friendly Version

Interactive Discussion 
Table 1. Drought degrees of the relative soil moisture.

\begin{tabular}{lcccc}
\hline Degree & Mild & Moderate & Severe & Extraordinary \\
\hline Relative soil moisture $W$ & $50<W \leq 60$ & $40<W \leq 50$ & $30<W \leq 40$ & $W \leq 30$ \\
\hline
\end{tabular}

Impacts of drought

on the quality of

surface water of the basin

B. B. Huang et al.

Title Page

Abstract

Introduction

Conclusions

References

Tables

Figures

14

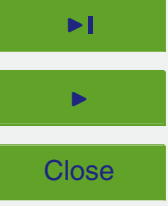

Back

Full Screen / Esc

Printer-friendly Version

Interactive Discussion 
Table 2. Simulation test of rainfall duration.

\begin{tabular}{llllll}
\hline $\begin{array}{l}\text { Rainfall duration } \\
\text { Drought degree }\end{array}$ & $0.5 \mathrm{~h}$ & $1 \mathrm{~h}$ & $2 \mathrm{~h}$ & $4 \mathrm{~h}$ & $8 \mathrm{~h}$ \\
\hline Mild & $\mathrm{D}_{11}$ & $\mathrm{D}_{12}$ & $\mathrm{D}_{13}$ & $\mathrm{D}_{14}$ & $\mathrm{D}_{15}$ \\
Moderate & $\mathrm{D}_{21}$ & $\mathrm{D}_{22}$ & $\mathrm{D}_{23}$ & $\mathrm{D}_{24}$ & $\mathrm{D}_{25}$ \\
Severe & $\mathrm{D}_{31}$ & $\mathrm{D}_{32}$ & $\mathrm{D}_{33}$ & $\mathrm{D}_{34}$ & $\mathrm{D}_{35}$ \\
extraordinary & $\mathrm{D}_{41}$ & $\mathrm{D}_{42}$ & $\mathrm{D}_{43}$ & $\mathrm{D}_{44}$ & $\mathrm{D}_{45}$ \\
\hline
\end{tabular}

HESSD

10, 14463-14493, 2013

Impacts of drought

on the quality of

surface water of the basin

B. B. Huang et al.

Title Page

Abstract

Introduction

Conclusions

References

Tables

Figures

14

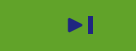

4

Back

Close

Full Screen / Esc

Printer-friendly Version

Interactive Discussion 
Table 3. Simulation test of rainfall intensity.

\begin{tabular}{lcccc}
\hline $\begin{array}{l}\text { Rainfall duration } \\
\text { Drought degree }\end{array}$ & Mild & Moderate & Severe & Extraordinary \\
\hline $2 \mathrm{mmmin}^{-1}$ & $\mathrm{P}_{11}$ & $\mathrm{P}_{12}$ & $\mathrm{P}_{13}$ & $\mathrm{P}_{14}$ \\
$2.5 \mathrm{~mm} \mathrm{~min}^{-1}$ & $\mathrm{P}_{21}$ & $\mathrm{P}_{22}$ & $\mathrm{P}_{23}$ & $\mathrm{P}_{24}$ \\
$3.5 \mathrm{~mm} \mathrm{~min}^{-1}$ & $\mathrm{P}_{31}$ & $\mathrm{P}_{32}$ & $\mathrm{P}_{33}$ & $\mathrm{P}_{34}$ \\
\hline
\end{tabular}

HESSD

10, 14463-14493, 2013

Impacts of drought

on the quality of

surface water of the basin

B. B. Huang et al.

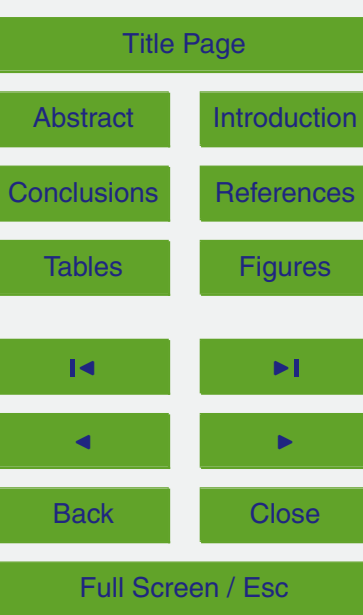

Printer-friendly Version

Interactive Discussion 
Table 4. Basic soil property.

\begin{tabular}{lccccc}
\hline Soil type & $\begin{array}{c}\text { Unit weight } \\
\left(\mathrm{g} \mathrm{cm}^{-3}\right)\end{array}$ & $\begin{array}{c}\text { Total porosity } \\
(\%)\end{array}$ & $\mathrm{pH}$ & $\begin{array}{c}\text { Organic matter } \\
\left(\mathrm{g} \mathrm{kg}^{-1}\right)\end{array}$ & $\begin{array}{c}\text { Soil capacity } \\
(\%)\end{array}$ \\
\hline Fluvo-aquic & 1.40 & 50.3 & 8.00 & 11.05 & 23.6 \\
\hline
\end{tabular}

HESSD

10, 14463-14493, 2013

Impacts of drought

on the quality of

surface water of the basin

B. B. Huang et al.

Title Page

Abstract

Introduction

Conclusions

References

Tables

Figures

14

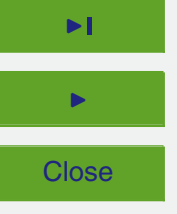

Back

Full Screen / Esc

Printer-friendly Version

Interactive Discussion 
Table 5. Leaching rate of ammonium nitrogen under different alternating scenarios of drought and flood.

\begin{tabular}{lcccc}
\hline $\begin{array}{l}\text { Drought degree } \\
\text { Rainfall intensity }\end{array}$ & Mild & Moderate & Severe & Extraordinary \\
\hline $2 \mathrm{~mm} \mathrm{~min}^{-1}$ & $1.82 \%$ & $2.16 \%$ & $2.67 \%$ & $3.22 \%$ \\
$2.5 \mathrm{~mm} \mathrm{~min}^{-1}$ & $1.93 \%$ & $2.31 \%$ & $3.12 \%$ & $3.60 \%$ \\
$3.5 \mathrm{~mm} \mathrm{~min}^{-1}$ & $2.38 \%$ & $3.19 \%$ & $3.73 \%$ & $4.15 \%$ \\
\hline
\end{tabular}

\section{HESSD}

10, 14463-14493, 2013

Impacts of drought

on the quality of

surface water of the basin

B. B. Huang et al.

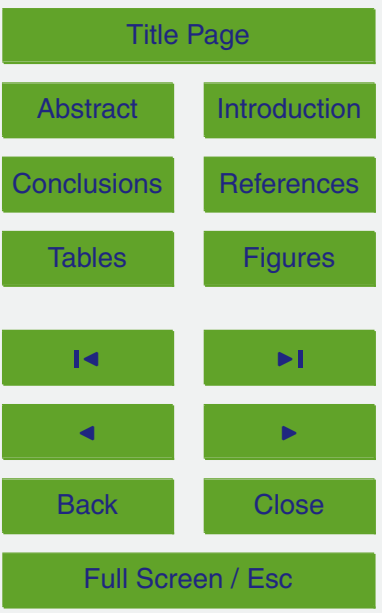

Printer-friendly Version

Interactive Discussion 
Table 6. Leaching rate of nitrate nitrogen under different alternating scenarios of drought and flood.

\begin{tabular}{lcccc}
\hline $\begin{array}{l}\text { Drought degree } \\
\text { Rainfall intensity }\end{array}$ & Mild & Moderate & Severe & Extraordinary \\
\hline $2 \mathrm{~mm} \mathrm{~min}^{-1}$ & $19.68 \%$ & $23.54 \%$ & $27.45 \%$ & $31.84 \%$ \\
$2.5 \mathrm{~mm} \mathrm{~min}^{-1}$ & $22.30 \%$ & $26.86 \%$ & $33.00 \%$ & $36.25 \%$ \\
$3.5 \mathrm{~mm} \mathrm{~min}^{-1}$ & $28.19 \%$ & $31.18 \%$ & $36.09 \%$ & $42.13 \%$ \\
\hline
\end{tabular}

\section{HESSD}

10, 14463-14493, 2013

Impacts of drought

on the quality of

surface water of the basin

\section{B. B. Huang et al.}

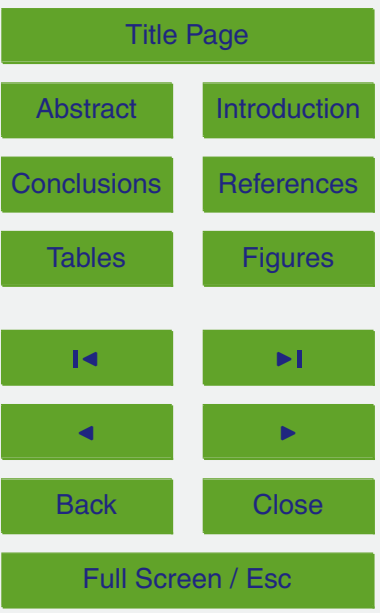

Printer-friendly Version

Interactive Discussion 
Table 7. Leaching rate of ammonium nitrogen under different alternating scenarios of drought and flood.

\begin{tabular}{lcccc}
\hline $\begin{array}{l}\text { Drought degree } \\
\text { Rainfall intensity }\end{array}$ & Mild & Moderate & Severe & Extraordinary \\
\hline $2 \mathrm{~mm} \mathrm{~min}^{-1}$ & $4.16 \%$ & $4.97 \%$ & $6.06 \%$ & $6.92 \%$ \\
$2.5 \mathrm{~mm} \mathrm{~min}^{-1}$ & $4.67 \%$ & $5.66 \%$ & $6.06 \%$ & $6.63 \%$ \\
$3.5 \mathrm{~mm} \mathrm{~min}^{-1}$ & $4.96 \%$ & $6.28 \%$ & $7.38 \%$ & $9.01 \%$ \\
\hline
\end{tabular}

\section{HESSD}

10, 14463-14493, 2013

Impacts of drought

on the quality of

surface water of the basin

B. B. Huang et al.

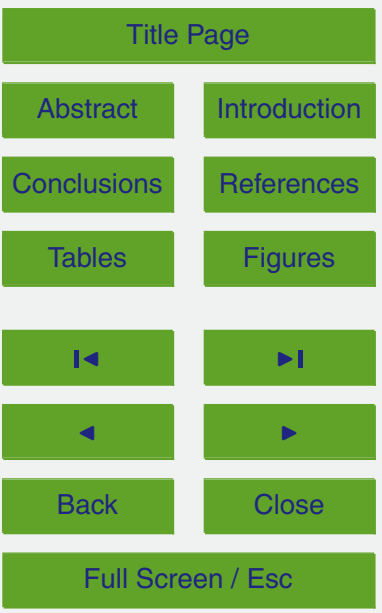

Printer-friendly Version

Interactive Discussion 
Table 8. Pollution-yield rate of nitrate nitrogen under different alternating scenarios of drought and flood.

\begin{tabular}{lcccc}
\hline $\begin{array}{l}\text { Drought degree } \\
\text { Rainfall intensity }\end{array}$ & Mild & Moderate & Severe & Extraordinary \\
\hline $2 \mathrm{~mm} \mathrm{~min}^{-1}$ & $52.07 \%$ & $57.03 \%$ & $62.46 \%$ & $68.21 \%$ \\
$2.5 \mathrm{~mm} \mathrm{~min}^{-1}$ & $53.72 \%$ & $60.12 \%$ & $65.88 \%$ & $69.81 \%$ \\
$3.5 \mathrm{~mm} \mathrm{~min}^{-1}$ & $58.65 \%$ & $64.83 \%$ & $70.71 \%$ & $76.40 \%$ \\
\hline
\end{tabular}

\section{HESSD}

10, 14463-14493, 2013

Impacts of drought

on the quality of

surface water of the basin

\section{B. B. Huang et al.}

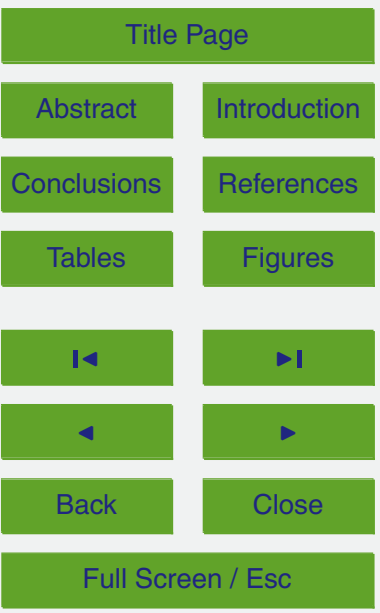

Printer-friendly Version

Interactive Discussion 
Table 9. Number of continuous days of effective rainfall free during crop growth period.

\begin{tabular}{llcccc}
\hline & Drought & Mild & Moderate & Severe & Extraordinary \\
\hline $\begin{array}{l}\text { Days of } \\
\text { rainfall }\end{array}$ & Spring (Mar-May); & $15 \sim 30$ & $31 \sim 50$ & $51 \sim 75$ & $>75$ \\
\cline { 2 - 6 } free & Sutumn (Sep-Nov) & & & & \\
\cline { 2 - 6 } & Summer (Jun-Aug) & $10 \sim 20$ & $21 \sim 35$ & $36 \sim 50$ & $>50$ \\
\hline
\end{tabular}

Effective rainfall free refers to daily precipitation amount in Spring and Autumn $<3 \mathrm{~mm}$; daily precipitation amount in summer $<5 \mathrm{~mm}$.

Impacts of drought

on the quality of

surface water of the basin

B. B. Huang et al.

Title Page

Abstract

Introduction

Conclusions

References

Tables

Figures

14

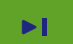

4

Back

Close

Full Screen / Esc

Printer-friendly Version

Interactive Discussion 

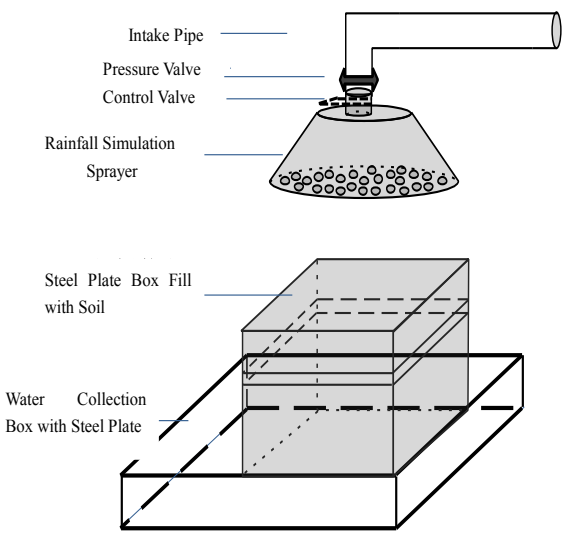

(a)

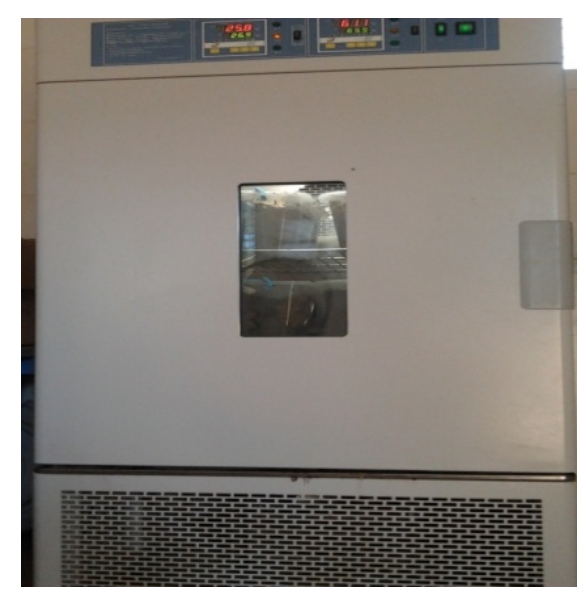

(b)

\section{HESSD}

10, 14463-14493, 2013

Impacts of drought

on the quality of

surface water of the basin

B. B. Huang et al.

\section{Title Page}

Abstract

Introduction

Conclusions

References

Tables

Figures

14

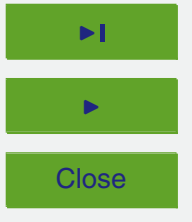

Back

Full Screen / Esc

Printer-friendly Version

Interactive Discussion 


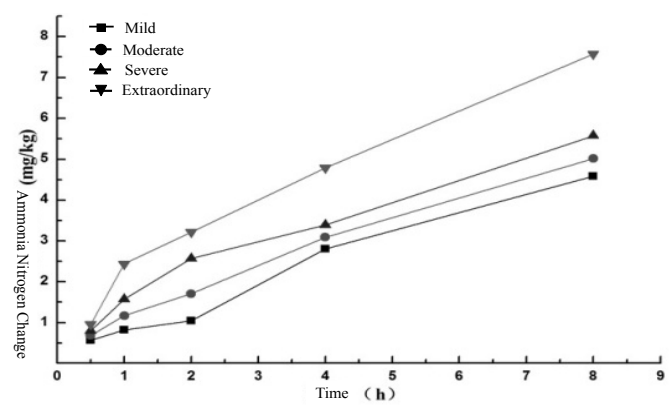

(a)

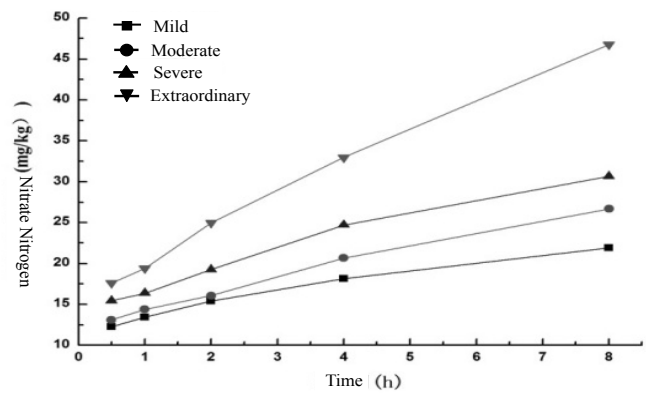

(b)

Fig. 2. Impacts of rainfall duration on the ammonia nitrogen and nitrate nitrogen loss in soil.

HESSD

10, 14463-14493, 2013

Impacts of drought

on the quality of

surface water of the basin

B. B. Huang et al.

Title Page

Abstract

Introduction

Conclusions

References

Tables

Figures

14

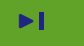

4

Back

Close

Full Screen / Esc

Printer-friendly Version

Interactive Discussion 


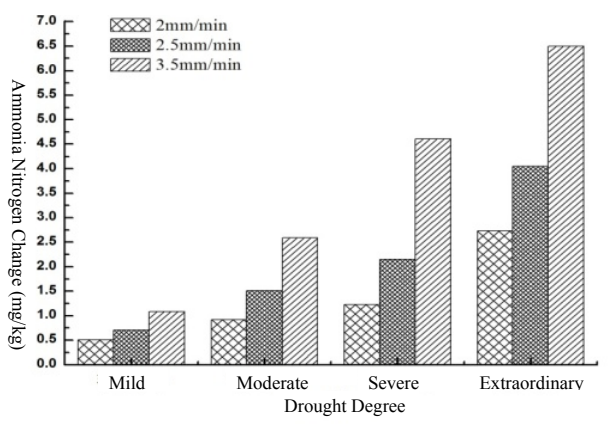

(a)

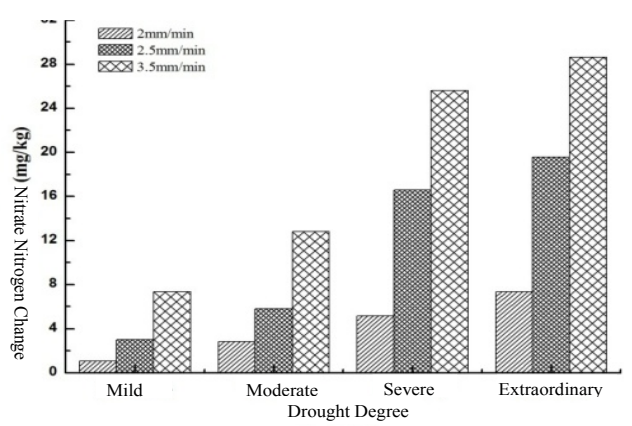

(b)

Fig. 3. Impacts of rainfall intensity on the nitrogen loss in the soil.

\section{HESSD}

10, 14463-14493, 2013

Impacts of drought

on the quality of

surface water of the basin

B. B. Huang et al.

\section{Title Page}

Abstract

Introduction

Conclusions

References

Tables

Figures

14

4

Back

Full Screen / Esc

Printer-friendly Version

Interactive Discussion 


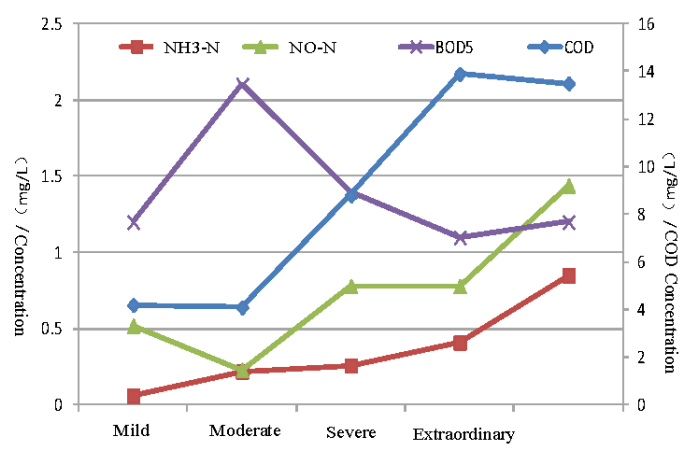

(a) Kumotun

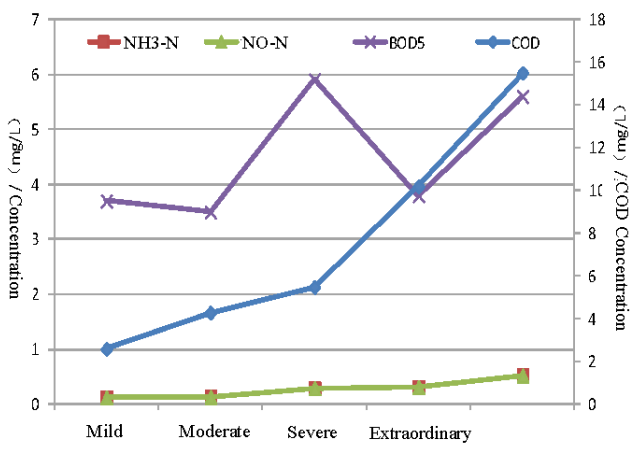

(c) Jiangqiao

Fig. 4. Changes of water quality under various drought degrees and of the first rainfall after the drought in Nenjiang Basin in 2000-2006.

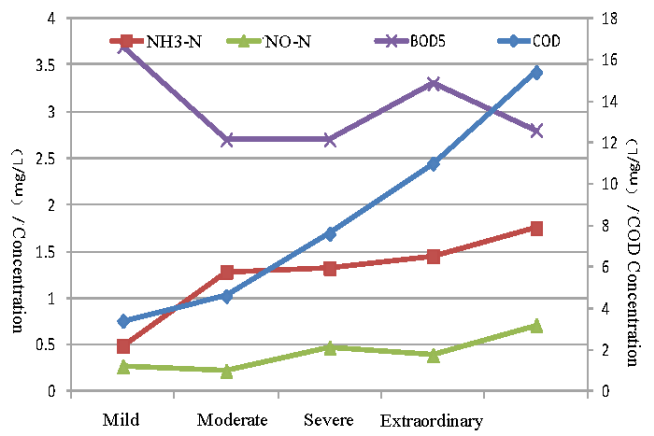

(b) Fulacrji

\section{HESSD}

$10,14463-14493,2013$

Impacts of drought

on the quality of

surface water of the basin

B. B. Huang et al.

Title Page

Abstract

Introduction

Conclusions

References

Tables

Figures

14

I

4

Back

Close

\section{Full Screen / Esc}

Printer-friendly Version

Interactive Discussion 